\begin{abstract}
Volodymyr Sidak,
Doctor of Historical Sciences, Candidate of Judicial Sciences, Professor, Corresponding Member of the Pedagogical Academy of Sciences of Ukraine, Professor of the Department of Financial and Economic Security Management, «KROK» University, Kyiv, Ukraine
\end{abstract}

ORCID iD 0000-0001-5649-6234

e-mail: sidak@krok.edu.ua

Yana Koval,

Candidate of sciences in public administration, assistant professor of the department of financial and economic security, «KROK» University, Kyiv, Ukraine

\title{
ANTI-CRISIS MANAGEMENT ECONOMIC SAFETY OF BANKING INSTITUTIONS ON THE STATE LEVEL: PROBLEMS AND WAYS OF THEIR SOLUTION
}

\begin{abstract}
Annotation. The development of the economy directly depends on the state of the banking system, financing and servicing of enterprises by banking institutions. A prerequisite for this is to ensure a stable financial position of banks, which is the main task of both their owners and the regulator of the banking sector. In transition economies with poorly developed financial markets, in most cases, banks are the only institutions that form the necessary information for financial intermediation, provide diversification of financial resources, reduce the level of risk of financial activity, and promote the implementation of leading standards of corporate governance. Even in economically developed countries, banks remain centers of financial and economic activity, while taking a special place among financial institutions as instruments of making credit investments, creating savings and ensuring payments. In addition, stability is extremely important given the functions of financial intermediation, the provision of cash flow, customer satisfaction in financial services, the efficient allocation of credit resources and the maintenance of financial discipline among borrowers. In transition economies with poorly developed financial markets, in most cases, banks are the only institutions that form the necessary information for financial intermediation, provide diversification of financial resources, reduce the level of risk of financial activity, and promote the implementation of leading standards of corporate governance. Even in economically developed countries, banks remain centers of financial and economic activity, while taking a special place among financial institutions as instruments of making credit investments, creating savings and ensuring payments. In the article, the directions of improvement of the mechanism of state regulation of anti-crisis management by the economic security of banking institutions of Ukraine are systematized by systematizing the main measures, which are united in the main directions, in particular such as: the period of implementation; by the entities that implement them; on the mechanisms of implementation; by types of banking activity.
\end{abstract}

Key words: public administration; the mechanism of public administration; anti-crisis management; economic security; banking institutions; diversification. 


\section{INTRODUCTION}

The biggest problems of the last world crisis have caused the banking sector to be incapacitated to withstand its challenges, to adapt mobile to constant changes in the market environment, through the problem of «bad» assets banks have suffered significant losses. The implementation of specific anti-crisis measures at the level of an individual banking institution using the tools available to management and bank shareholders should be considered during analysis of the functional component of the crisis management of the banking institution. Such a component of crisis management is characterized by the use of analytical tools for forecasting and planning (stress-testing of major risks, plans for crisis management); organizational and managerial tools (cost optimization, outsourcing certain types of activities).

The economic mechanism of crisis management should be an integral part of the management of the bank, and consist of three subsystems: security subsystem, functional and control subsystem problem assets. The first subsystem includes the components of organizational, methodological, normative, financial, informational and technical support. The second subsystem is united functions of crisis management and is a complex of economic and organizational methods that help solve the problems of bank diagnostics, analysis, control and timely preventing emerging crisis situations. The third is a subsystem of accounting, valuation, financial healing and overcoming other problems.

Formulation of the problem. The results of banking activities concern almost all spheres of the economy, their failures and achievements can lead to destruction or significant negative changes throughout the economic system. Under such conditions, banks need to focus on the formation and implementation of an effective system of crisis management, apply a special crisis mechanism to avoid crises, overcome the crisis and stabilize activity of the bank. The system should be permanent and monitor the state of the bank activities. All this will contribute to the reliability of the banking system, security and growth economy, protection of customer deposits. That is why studying the problems of crisis management the banking system of Ukraine is relevant.

Analysis of recent research and publications. The problem of the organization of effective crisis management banks and the banking system were engaged as domestic scientists, among them: G. Bagratyan, O. Baranovsky, V. Dzhulay, O. Drugov, R. Slavjuk, O. Chub, and foreign scientists: E. Demirhuk-Kuntom, I. Detragia, P. Krugman, G. Minski. Issues of ensuring financial stability and stability of both a bank and the banking system were given by such scholars as G. Azarenkova, O. Vovchak, O. Dzyublyuk, A. Kuznetsov, N. Sheludkoand others. Paying tribute to the authors of scientific works, the results of which contributed to the process of formation of public administration, it should be noted that the issue of creating and functioning of the mechanism of state regulation of crisis management of the economic security of banking institutions is not sufficiently deep and requires further comprehensive study.

The purpose of the article. The purpose of the article is to study the problems of anticrisis management economic safety of banking institutions at the state level and proposing their resolution.

\section{RESEARCH RESULTS}

State regulation of the financial services market, among which the chairman is the banking system, was carried out at all stages of its development, and, despite the change of prevailing economic theories, the methods of this regulation remained constant.

Modern market realities (internationalization, transformation of the global banking sector, expanding the scope of activities, activating investment activity, liberalizing the movement of foreign capital, diversifying the leadership positions of banking activities, concentration of international banking capital) put banks' requirements on stability, competitiveness, ability to integrate into the world of space. Integration into the world financial space requires improvement of the system of legislative regulation of banking activity.

In domestic and foreign sciences, extensive research has been carried out on the system of economic security of banking institutions, although the process of systematization of their economic security continues. For example, some issues are still not addressed, in particular, the assessment of the impact of state regulation on the system of economic security of banking institutions. Thus, the necessity of theoretical substantiation and improvement of the assessment of the influence of state regulation on the system of economic security of banking institutions determined the choice of the topic of the dissertation, its relevance and practical significance.

Improving the state regulation mechanism of the crisis management of the economic security of banking institutions in Ukraine will provide an opportunity to provide higher indicators of the level of economic security of banks compared to those that could be stated now, which in the future will positively affect the state of the banking system as a whole. 
The state regulation mechanism of crisis management of economic security in banking institutions in Ukraine is implemented through the forms, methods, techniques and tools, which were described in detail in the first section of the study [1].

In the context of deepening international banking competition and significant impact on the domestic banks of the effects of the global financial crisis, state regulation of banking activities requires new approaches to the development and application of state measures and instruments of influence on banking activities in order to ensure the stability of the banking system and growth of the domestic economy. At this stage of development of domestic banking special attention of scientists and practitioners needs to study the conditions and factors of state regulation of banking activities - a system that performs functions of forming banking legislation and conducting banking supervision.

The need for state regulation of the economy atvariousstagesofdevelopment ofsocietyhasacquired ambiguous direction. Modern state regulation does not envisage the total absorption of the economic sphere, as was the case with the commandadministrative system of management. The economic policy of the state is, to a greater or lesser extent, used to support socio-economic stability at both the state and regional levels.

At the same time, it is expedient to use the norms of banking activity of the National Bank of Ukraine only in order to establish the level of financial security of the bank for various kinds of hazards and threats, as well as its financial stability. At the same time, the corporate resources of banking institutions, the protection of which should be a priority task of a highly organized system of economic security of the bank, is not limited to its assets, investment resources, monetary funds in the accounts and shareholder's equity [2].

In order to solve the existing problems in the functioning of banking institutions, it is necessary to formulate an algorithm of actions in accordance with the developed state regulation mechanism of crisis management of the economic security of banking institutions in Ukraine [3] (Tabl. 1).

CLASSIFICATION OF IMPROVEMENT MEASURES OF CRISIS MANAGEMENT OF ECONOMIC SECURITY OF BANKING INSTITUTIONS IN UKRAINE

\begin{tabular}{|c|c|c|}
\hline № & Directions of implementation & Ways of implementation \\
\hline 1 & by implementation period & Strategic; Tactical; \\
\hline 2 & by implementing subjects & $\begin{array}{l}\text { Ministry of Finance of Ukraine; National Bank of Ukraine; } \\
\text { Basel Committee; International Monetary Fund; }\end{array}$ \\
\hline 3 & by implementation mechanisms & Legal; Informational; Organizational; Economic; Social; Normative; \\
\hline 4 & by bank economic activity & External; Internal; Universal; Special; Functional. \\
\hline
\end{tabular}

\section{Source: compiled by authors}

It is necessary to consider each of the proposed measures in more detail to improve the crisis management of the economic security of banking institutions in Ukraine.

I) By implementation period:

- tactical - improving the internal organization of work: improving the rules and procedures for implementing various banking transactions, improving the work of bank personnel engaged in passive operations, finding new forms of work with customers, reducing the likelihood of risk and inappropriate decisions, etc.;

- strategic - aimed at strengthening its position in the market, which envisages taking into account the whole complex of factors that create the external environment for banking activities.

II) By implementing subjects:

1) Ministry of Finance of Ukraine: by managing public finances that can provide high-quality public services, effectively accumulating resources and distributing them in accordance with the priorities of the development of the nation in the mediumand long-term perspective through:

- full implementation of strategic and mediumterm planning, which will ensure the allocation of resources in accordance with the state's priorities;

- introduction of effective planning and evaluation systems of state regulation implementation, 
increasing the role and responsibility of the main spending units in determining priorities of their activities and efficient use of funds for their achievement;

- increasing the state regulation effectiveness through a comprehensive analysis of feasibility and effectiveness through changes in approaches to their implementation through the transition from institutional maintenance to the provision of qualitative public services;

- strengthening control over bank risks and taking measures to minimize them, in particular regarding banking institutions, state guarantees and other debt offerings;

- provision of strategic distribution and monitoring of state investments;

- supporting the decentralization process by ensuring a clear distribution of relevant authorities and resources, as well as ensuring the accountability of banking institutions;

- increasing the level of managerial accountability and effectiveness of internal control and audit in central and local government bodies.

1) National Bank of Ukraine:

- low and stable inflation - deepening the transmission mechanism of monetary policy and setting a discount rate at a level that will bring expected inflation to target values at the political horizon;

- stable and transparent effective banking system - transition to risk-oriented banking supervision: analysis of business models and strategies of banks;

- annual stress testing; strengthened control of bank operations with related parties. Harmonization of the prudential requirements for banks with the norms of the European Union legislation and the recommendations of the Basel Committee;

- restoration of lending - start of work of the Credit register. Strengthening consumer rights protection, strengthening the protection of creditors' rights: improving bankruptcy procedures; the establishment of the institution of private performers;

- effective regulation of the financial sector definition of target model of financial sector regulators functioning (SPLIT project);

- free capital movement - currency restrictions liberalization (depending on macroeconomic conditions) in relation to: operations under the current account and the account of direct foreign investments, portfolio investment and credit operations of legal entities; financial transactions of individuals;

- financial inclusion - development of payment infrastructure through: transfer of transactions in electronic channels: development of electronic payments;

- a modern, open, independent, efficient central bank.

In our opinion, the transformation of the National Bank has two main directions:

1. Process direction provides an effective decision-making system for achieving goals through:

- development of analytical and research potential, regular and clear informing of society and markets as main tool of constructive influence;

- ensuring a transparent and effective process of development and implementation of regulatory decisions;

- systems of proper internal control and risk minimization.

2. Resource direction develops the adaptability of the National Bank's internal resources to strategic objectives through:

- development of a new leadership and focus on personality, formation of teams;

- development of modern information infrastructure, ensuring a high level of automation of processes;

- development of a culture of economical and efficient use of national resources.

At the same time, we propose to unite the participants of the financial system into six client groups according to their role:

- experts (create the basis for the development of qualitative regulations);

- subjects of economic and financial state policy (create an effective legal framework for all participants in the financial market);

- entities of financial activity (provide access to financial services and resources, risk management, investment security and savings);

- subjects of economic activity (produce goods and services, provide economic growth);

- the nation as a provider of services (ensures the welfare of the country and the free access to public services necessary for a healthy life and effective economic activity);

- citizens of Ukraine (decide on consumption and savings to maximize their own welfare) (Table 2).

Within their role in the system, each client performs some functions, offering others a certain value, which he creates independently or jointly with the National Bank. The exchange of valuables takes the form of certain products or services that meet the needs of clients and client groups.

The National Bank interacts with all client groups. Created values satisfy the needs of each client group and can multiply in the process of interaction with other participants of the financial ecosystem. 
MAIN TASKS OF CLIENT GROUPS OF BANKING INSTITUTIONS IN UKRAINE

\begin{tabular}{|c|c|c|c|}
\hline Client groups & $\begin{array}{c}\text { Who belongs } \\
\text { to client groups }\end{array}$ & $\begin{array}{c}\text { What client needs have } \\
\text { to be satisfied }\end{array}$ & $\begin{array}{c}\text { What value produce } \\
\text { the products of banking } \\
\text { institutions }\end{array}$ \\
\hline Experts & $\begin{array}{c}\text { International } \\
\text { organizations, expert } \\
\text { media, separate experts }\end{array}$ & $\begin{array}{c}\text { Promoting the effectiveness } \\
\text { of approved decisions, } \\
\text { access to information }\end{array}$ & $\begin{array}{c}\text { Environment } \\
\text { for the development } \\
\text { of market rules }\end{array}$ \\
\hline $\begin{array}{c}\text { Subjects of economic } \\
\text { and financial state } \\
\text { policy }\end{array}$ & $\begin{array}{c}\text { Governmental } \\
\text { regulating institutions }\end{array}$ & $\begin{array}{c}\text { Creation of qualitative } \\
\text { and effective activity rules } \\
\text { in the market }\end{array}$ & $\begin{array}{c}\text { Effective interaction model } \\
\text { of and expert assistance }\end{array}$ \\
\hline $\begin{array}{c}\text { she state as a services } \\
\text { supplier }\end{array}$ & $\begin{array}{c}\text { Public institutions } \\
\text { providing social } \\
\text { security }\end{array}$ & $\begin{array}{c}\text { Macroeconomic stability, } \\
\text { national economic } \\
\text { development }\end{array}$ & $\begin{array}{c}\text { Development of modern } \\
\text { financial sector infrastructure } \\
\text { and financial inclusion }\end{array}$ \\
\hline $\begin{array}{c}\text { Citizens of Ukraine } \\
\text { Individuals / } \\
\text { households }\end{array}$ & $\begin{array}{c}\text { Preservation of real value } \\
\text { of incomes and savings, } \\
\text { convenient calculations }\end{array}$ & $\begin{array}{c}\text { Preservation of purchasing } \\
\text { power, protection } \\
\text { of consumers' rights } \\
\text { to financial services }\end{array}$ \\
\hline
\end{tabular}

Source: compiled by authors

2) Basel Committee:

- development and implementation of Basel IV, the rules of which are to a large extent to strengthen capital requirements by means of calculating the risk weighted assets (RWA);

- increase of the first-tier capital adequacy ratio of banks that do not wish or cannot increase the fixed capital, which will be forced to reduce the volume of risky operations, in particular, to reduce the level of lending, which will lead to a decrease in the profit of banks.

2) International Monetary Fund:

- ensuring financial stability through the formation of an effective monetary and credit policy to ensure price stability;

- flexibility of exchange rates and a comprehensive strategy to strengthen the financial position of banks through recapitalization of banks, lending and the settlement of troubled assets, which will have a significant impact on the restoration of public confidence in banking structures;

- strengthening of public finances. The revision of expenditures and their reduction will ensure budget consolidation in the next period;

- continuing of structural reforms. Includes governance reforms, including the fight against corruption and judicial measures, tax administration reforms, and the reform of state-owned enterprises in order to improve the quality of management and reduce fiscal risks;

- development, broad discussion and approval of international standards for banking operations, monetary and fiscal policy, statistics of payments balance;

- conducting research, analysis and forecasting of the development of the world economy and international financial markets;

- temporary provision of the Fund's common resources to the member states (with appropriate guarantees) in order to remedy the imbalances in their balance of payments, avoiding any measures that could harm the national or international level.

III) By implementation mechanisms:

1) Legal mechanisms:

- gradual integration of Ukraine into the European legal field and harmonization of national legislation with international standards;

- accelerate the adoption of laws and strengthen the weak interaction of state bodies in ensuring the development of the financial sector;

- legal proceedings and enforcement proceedings systems must work effectively resulting in strong protection of the rights of creditors;

- improve the system of protection of consumer rights of financial services in Ukraine.

1) Information mechanisms:

- provision of constitutional rights and freedoms for the collection, storage, use and dissemination of information;

- full satisfaction of the needs of citizens, enterprises and organizations of all forms of ownership in access to reliable and objective information; 
- effective interaction of public authorities and civil society institutions during the formation and implementation of state policy in the information sphere;

- protection of national secrets and other information, the protection requirements of which are established by law;

- forming a positive image of Ukraine in the world, reporting prompt, reliable and objective information on events in Ukraine to the international community.

1) Organizational measures:

- changing the models of classical banking in the world: the emergence of new, alternative payment systems, instruments of payment and lending;

- reduce the risk of cyber attacks;

- improve the development of national information databases (demographic registry, electronic receipts, etc.).

2) Economic measures:

- it is necessary to achieve macro-financial stabilization, the economy should gradually recover, but it remains vulnerable to shocks;

- to diversify foreign trade, reduce dependence on one partner;

- significant openness of the economy;

- high level of market monopolization.

3) Social measures:

- It is necessary to develop a system for protecting the rights of financial services consumers and to expand the financial inclusion in the world is necessary;

- conflict in eastern Ukraine is a permanent source of risks for the country and its economy; the rapid withdrawal of the country from this state will affect the economic situation;

- increase of the birth rate in Ukraine, as «rejuvenation» of clients will promote the innovative development of banking institutions of Ukraine;

- raising the level of the national currency, because its low level only increases the distrust of the population to the banking institutions in Ukraine.

4) Normative measures:

- introduction of norms, which will give an opportunity to more accurately assess the status of banking institutions;

- application of effective instruments of refinancing policy, taking into account the experience of developed countries of the world;

- improvement of interest rate policy, in particular lowering the discount rate, which will affect interest rates on the market and the availability of borrowed funds;

- use of an effective method for evaluating the financial stability of the bank, which will determine the real financial condition of the bank and reduce the risk of non-repayment of the refinancing loan.

5) By bank economic activity:

- internal and external - through introducing clear conditions for the functioning of banking institutions, reducing the appearance of shadow schemes, creating favorable conditions for increasing the level of economic security of banking institutions;

- universal and special - the use or full transition to the new standards of banking institutions, the implementation of European norms and standards, the introduction of economic mechanisms for the development of banking institutions and ensuring an effective partnership between the state and the banking institutions of Ukraine.

We believe that the proposed classification of measures to improve the crisis management of economic security of banking institutions in Ukraine will promote a more reasonable identification of threats to the national economic development not only in general, but also specifically for each component. It is hardly possible to set specific threats and to submit specific offers without their selection for each of the indicated segments that are presented by:

- state regulation bodies;

- normative legal acts regulating activity;

- services provided;

- mechanisms for the services provision, etc.

At the current stage ofdevelopment of the banking sector of Ukraine, during the development of the anti-crisis strategies of the bank, the tools and mechanisms of anti-crisis communication policy are not actively used. The strategies for implementing anti-crisis communication policies have be differentiated and characterized by a unique set of communication channels, target audiences and content of information messages the bank. With a view to a more integrated and systematic approach to crisis management communications, banking institutions' management should use more actively the tools of «interaction with investors», «interaction with state structures», anti-crisis communication program and reputation rating of the bank directed, first of all, to the expert- analysts.

In order to apply the most adequate anti-crisis instruments, depending on the source of the crisis and the degree of influence of crisis phenomena on theactivities of thebankinginstitution, itisnecessary to distinguish certain stages of the implementation of anti-crisis measures. For a "preventive» phase, early identification of crisis phenomena and prediction of potential losses through analytical tools is characteristic; taking measures aimed at preventing 
the development of crisis processes. At the stage of «emergence of a crisis state», when crisis trends are beginning to appear in the bank, priority measures are being implemented to minimize the impact of crisis phenomena (reduction of administrative costs, operational support for liquidity). At the stage of «active counteraction to the spread of the crisis» the normal functioning of the banking institution is problematic, which entails the need for more large-scale anti-crisis measures (sale of a significant volume of a portfolio of problem loans, increase of authorized capital). The improved procedure for the implementation of anti-crisis measures by banking institutions, which simultaneously covers the functional and institutional aspects of crisis management, has the following components: identification of the crisis state; analytical assessment of the scale of the crisis and the probable losses of the bank from it; operational measures to support liquidity, asset quality improvement and capitalization (core of the system); methodical tool for evaluating the effectiveness of using the specified procedure.

The main characteristics of this procedure are a necessity observance of a clear sequence of implementation of anti-crisis measures (from the priority solution of the problem of insufficient liquidity to ensuring an adequate level of capitalization as the ultimate goal of implementing the above-mentioned measures); its high degree of adaptability to changes in the internal and external conditions of the bank. The basis of the evaluation of the effectiveness of applying the improved procedure of crisis management of the bank is the comparison of costs for the implementation of anti-crisis measures (the formulation of reserves, the implementation of anti-crisis communication policy, etc.) with the available financial resources of shareholders. In the case where the size of such financial resources does not exceed the amount necessary for the implementation of anti-crisis measures of expenditure, is considered the issue of selling the bank to new shareholders or initiating a bank liquidation procedure.

Theeffectiveness oftheaboveprocedureisensured by the presence of such functional subsystems in a banking institution: corporate governance focused on proper risk management; Personnel possessing the necessary skills for implementation of anticrisis measures; tools for communicating with government agencies, participants in the banking market and the public. The procedure for managing troubled assets has the following components: an analytical preliminary assessment of problem debt (in particular, the development of individual loans), the use of specific tools (restructuring, writeoff at the expense of reserves), the development and monitoring of the implementation of the schedule of reducing the share and volume of problem debt, assessing the effectiveness of collection. Improved mechanism

The work of the sanation institution for working with problem assets is based on the German experience of the operation of a hospital bank. Its fundamental principles are the purchase of a bad repayment institution for bad loans, a mandatory repurchase by the bank of troubled assets in a sanitary institution (the possibility of adjusting the discount at reverse repurchase, depending on the effectiveness of collection) and the formation of part of the resource base of the rehabilitation institution at the expense of funds attracted on the market. A balanced use of communication policy by the bank increases efficiency of crisis management by the banking institution. In addition to measures to form the content of information messages, to identify target audiences, and to apply specific communication channels, banking institutions should actively use tools for «communicating with investors», "communication with government agencies», and a reputational rating that is oriented towards an expert-analyst environment.

Failure to take into account these features or to give them insufficient attention will lead to mistakes in identifying bank risks and ineffective functioning of individual segments and banking institutions as a whole, which may lead to a disturbance of the balance and the emergence of a financial crisis.

Therefore, we believe that the proposed measures to improve the state regulation mechanism of the crisis management of the economic security of banking institutions at the national level will promote the development of banking institutions taking into account macro- and micro-features, which will serve as a basis for strengthening the stability of the banking system and preventing bank crises.

\section{CONCLUSIONS AND PERSPECTIVES FOR FURTHER STUDIES}

Anti-crisis management is extremely important right now, when after the world the financial crisis and its consequences, it is necessary to return the trust of customers to banks, elements of the crisis management should be implemented both at the level of NBU and commercial banks of Ukraine. State crisis management in banking institutions of Ukraine in general can be defined as medium as it requires highly skilled knowledge and skills from crisis managers management of banking structures in crisis processes and the availability of effective anti-crisis programs.

Anti-crisis management - a set of methods, techniques that allow you to recognize crises, to carry out their prevention, to overcome their negative consequences, to smooth the course 
of the crisis. State regulation of banking activity in a market economy is carried out, first of all, within the framework of the banking system itself and is reflected in the impact on the commercial banks of the National Bank of Ukraine. However, despite the presence of one regulatory entity in the regulation of the banking services market, the regulatory mechanisms for influencing the banking market in the context of the transformation of the world economy are complex and include a variety of instruments. Especially when the state faces a difficult task of finding the optimal option for securing economic security and stability on the one hand, and the need for economic growth and market efficiency on the other hand, there is an important issue of finding the most effective mechanism for regulating the banking services market, which will stimulate market development banking services and provide a positive effect.

\title{
REFERENCE (TRANSLATED AND TRANSLITERATED)
}

1. Stukalo N., Lytvyn M. State Crisis Regulation of the Banking Sector: Experience of the EU and Ukraine. Bulletin of the National Bank of Ukraine: scientific newsletter: collection of scientific articles. Kyiv: Publishing House of the National Bank of Ukraine. 2010. № 6. P. 20-25.

2. Dzybulyk O. Optimization of the formation of the commercial banks resource base. Banking: scientific practical journal. 2013. №. 5. P. 38-46.

3. Mihus I., Karpova K., Koval Y. Assessment of the NBU's measures of national crisis management in the banking sector. Investments: practice and experience: scientific professional edition 2017. №17. p. $82-90$.

\section{АНТИКРИЗОВЕ УПРАВЛІННЯ ЕКОНОМІЧНОЮ БЕЗПЕКОЮ БАНКІВСЬКИХ УСТАНОВ НА ДЕРЖАВНОМУ РІВНІ: ПРОБЛЕМИ ТА ШЛЯХИ ЇХ ВИРІШЕННЯ}

\author{
Сідак Володимир Степанович, \\ доктор історичних наук, кандидат юридичних наук, професор, \\ член-кореспондент Педагогічної академії наук України, \\ професор кафедри управління фінансово-економічною безпекою, \\ Вищий навчальний заклад «Університет економіки та права «КРОК», Київ, Україна \\ ORCID iD 0000-0001-5649-6234 \\ e-mail: sidak@krok.edu.ua
}

\section{Коваль Яна Сергіївна,}

кандидат наук з державного управління, доцент кафедри фінансово-економічної безпеки, Вищий навчальний заклад «Університет економіки та права «КРОК», Київ, Україна ORCID iD 0000-0001-6578-2996

e-mail:yanaks@krok.edu.ua

\begin{abstract}
Анотація. Розвиток економіки безпосередньо залежить від стану банківської системи, фінансування та обслуговування підприємств банківськими установами. Необхідною передумовою цього є забезпечення стабільного фінансового стану банків, що є основним завданням як їх власників, так і регулятора банківського сектору. У перехідних економіках з погано розвиненими фінансовими ринками у більшості випадків саме банки виступають єдиними інститутами, які формують необхідну для здійснення фінансового посередництва інформачію, забезпечують диверсифікацію розподілу фінансових ресурсів, зменшують рівень ризику фінансової діяльності та сприяють запровадженню провідних стандартів корпоративного управління. Навіть у економічно розвинених країнах банки залишаються иентрами фінансової та економічної активності, займаючи при цьому особливе місце серед фінансових інститутів як інструменти здійснення кредитних вкладень, створення заощаджень та забезпечення проведення платежів. Крім того, стабільність є надзвичайно важливою, зважаючи на функції фінансового посередничтва, забезпечення руху платіжних потоків, задоволення потреб клієнтів у фінансових послугах, ефективного розподілу кредитних ресурсів та підтримання фінансової дисципліни серед позичальників. У перехідних економіках з погано розвиненими фінансовими ринками у більшості випадків саме банки виступають єдиними інститутами, які формують необхідну для здійснення фінансового посередництва інформацію, забезпечують диверсифікацію розподілу фінансових ресурсів, зменшують рівень ризику фінансової діяльності та сприяють запровадженню провідних стандартів корпоративного управління. Навіть у економічно розвинених країнах банки залишаються центрами фінансової та економічної активності, займаючи при цьому особливе місце серед фінансо-
\end{abstract}



та забезпечення проведення платежів. У статmі систематизовано напрями вдосконалення механізму державного регулювання антикризовим управлінням економічною безпекою банківських установ України шляхом систематизації основних заходів, які об'єднано за основними напрямками, зокрема такими як: за періодом реалізації; за суб'єктами, які їх реалізовують; за механізмами реалізації; за видами банківської діяльності.

Ключові слова: державне управління; механізм державного управління; антикризове управління; економічна безпека; банківські установи; диверсифікація.

\section{АНТИКРИЗИСНОЕ УПРАВЛЕНИЕ ЭКОНОМИЧЕСКОЙ БЕЗОПАСНОСТЬЮ БАНКОВСКИХ УЧРЕЖДЕНИЙ НА ГОСУДАРСТВЕННОМ УРОВНЕ: ПРОБЛЕМЫ И ПУТИ ИХ РЕШЕНИЯ}

\section{Сидак Владимир Степанович,}

доктор исторических наук, кандидат юридических наук, профессор,

член-корреспондент Педагогической академии наук Украины,

профессор кафедры управления финансово-экономической безопасностью,

Высшее учебное заведение "Университет экономики и права «КРОК», Киев, Украина

ORCID iD 0000-0001-5649-6234

e-mail:sidak@krok.edu.ua

\section{Коваль Яна Сергеевна,}

кандидат наук по государственному управлению,

дочент кафедры финансово-экономической безопасности,

Высшее учебное заведение «Университет экономики и права «КРОК», Киев, Украина

ORCID iD 0000-0001-6578-2996

e-mail:yanaks@krok.edu.ua

Аннотация. Развитие экономики напрямую зависит от состояния банковской системы, финансирования и обслуживания предприятий банковскими учреждениями. Необходимым условием этого является обеспечение стабильного финансового состояния банков, является основной задачей как их владельцев, так и регулятора банковского сектора. В переходных экономиках с плохо развитыми финансовыми рынками в большинстве случаев именно банки выступают единственными институтами, которые формируют необходимую для осуществления финансового посредничества информацию, обеспечивают диверсификачию распределения финансовых ресурсов, уменьшают степень риска финансовой деятельности и способствуют внедрению ведущих стандартов корпоративного управления. Даже в экономически развитых странах банки остаются центрами финансовой и экономической активности, занимая при этом особое место среди финансовых институтов как инструменты осуществления кредитных вложений, создания сбережений и обеспечение проведения платежей. Кроме того, стабильность чрезвычайно важна, учитывая функции финансового посредничества, обеспечения движения платежных потоков, удовлетворение потребностей клиентов в финансовых услугах, эффективного распределения кредитных ресурсов и поддержания финансовой дисииплины среди заемщиков. В переходных экономиках с плохо развитыми финансовыми рынками в большинстве случаев именно банки выступают единственными институтами, которые формируют необходимую для осуществления финансового посредничества информачию, обеспечивают диверсификачию распределения финансовых ресурсов, уменьшают степень риска финансовой деятельности и способствуют внедрению ведущих стандартов корпоративного управления. Даже в экономически развитых странах банки остаются чентрами финансовой и экономической активности, занимая при этом особое место среди финансовых институтов как инструменты осуществления кредитных вложений, создания сбережений и обеспечение проведения платежей. В статье систематизированы направления совершенствования механизма государственного регулирования антикризисным управлением экономической безопасностью банковских учреждений Украины путем систематизации основных мероприятий, которые объединены по основным направлениям, в частности такими как: за периодом реализации; по субъектам, их реализующих; по механизмам реализации; по видам банковской деятельности.

Ключевые слова: государственное управление; механизм государственного управления; антикризисное управление; экономическая безопасность; банковские учреждения; диверсификация. 